\title{
MANFAAT DAN BIOAKTIVITAS DARI MANGGIS (Garcinia mangostana L.)
}

\author{
Marina Silalahi \\ Prodi Pendidikan Biologi, Fakultas Keguruan dan Ilmu Pendidikan, Universitas Kristen \\ Indonesia. \\ E-mail:marina_biouki@yahoo.com; marina.silalahi@uki.ac.id
}

\begin{abstract}
Garcinia mangostana L. is a fruit-producing plant and is widely used as an ingredient in traditional medicine. This study aims to explain the relationship between the utilization and bioactivity of G. mangostana. The writing of this article is based on a literature review on scientific articles published online using the keywords G. mangostana, uses of G. mangostana, and bioactivities of G. mangostana. The literature obtained was synthesized so that it could explain the benefits and bioactivity of $G$. mangostana. Local people in Southeast Asia have been used G. mangostana as a traditional medicine for the treatment of abdominal pain, diarrhea, dysentery, infected wounds, pus, and chronic ulcers. The results showed that G. mangostana has bioactivity as anti-microbial, antioxidant, anti-cancer, anti-inflammatory, and anti-diabetes Mellitus. The bioactivity of G. mangostana is related to the content of its secondary metabolites. $\alpha$-mangostin has antibacterial activity. Xanthones are chemical compounds that have pharmacological properties as anti-cancer, anti-inflammatory, and antimicrobial properties. The bioactivity of G. mangostana as an anti-microbial is the potential to be developed as a natural food coloring agent as well as a natural preservative.
\end{abstract}

Kata kunci: Garcinia mangostana, anti mikroba, anti kanker, mangosten

\section{PENDAHULUAN}

Manggis atau Garcinia mangostana L. merupakan salah satu tanaman penghasil buah yang mudah ditemukan di berbagai daerah Indonesia. Secara empirik terlihat kulit buah $G$. mangostana masih terbuang percuma, padahal kaya akan berbagai senyawa metabolit sekunder yang sangat bermanfaat untuk kesehatan (Yodhnu dkk. 2009). Masyarakat lokal di Asia Tenggara menggunakan $G$. mangostana sebagai obat tradisional untuk mengatasi berbagai penyakit seperti sakit perut, diare, disentri, luka dan infeksi ulkus (Pedraza-Chaverri dkk. 2008).

Pemanfaatan tumbuhan sebagai obat tradisional termasuk G. mangostana berhubungan dengan kandungan metabolit sekunder dan bioaktivitasnya. Sebagai contoh kandungan fenolik banyak dihubungkan dengan bioaktivitas sebagai antioksidan (Ngawhirunpat dkk. 2010). Informasi mengenai bioaktivitas sangat penting dalam pengembangan tumbuhan sebagai obat herbal terstandart maupun untuk fitofarmaka.

Beberapa tahun belakang ini, pemanfaatan $G$. mangostana sebagai bahan obat tradisional blooming dan diyakini dapat menyembuhkan berbagai penyakit seperti kanker, diabetes mellitus, dan gangguan jantung. Hal tersebut mengakibatkan masyarakat lokal di Indonesia mulai melirik G. mangostana sebagai alternatif terutama untuk mengatasi penyakit kanker. Kanker merupakan salah satu penyebab kematian pada manusia. Senyawa yang digunakan sebagai anti kanker merupakan senyawa yang mampu menghambat pertumbuhan sel atau mengakibatkan apostosis (Doi dkk. 2009; Aisha dkk. 2012). 
Ngawhirunpat dkk. (2010) melaporkan bahwa ekstrak metanol dan heksana perikarp G. mangostana mengandung menunjukkan $\alpha$-mangostin yang memiliki sifat sitotoksisitas sehingga dapat digunakan sebagai obat kanker. Perikarp buah $G$. mangostana kaya akan xanthones yang memiliki aktivitas sebagai anti kanker (Li dkk. 2013).

Selain sebagai anti kanker, $G$. mangostana juga banyak digunakan sebagai antioksidan (Azima dkk. 2017; Pedraza-Chaverri dkk. 2008; Kosem dkk. 2007), anti mikroba (Phuong dkk. 2017; Ragasa dkk. 2010; Suksamrarn dkk. 2003) dan anti diabetes mellitus (Ansori dkk. 2019). Informasi mengenai bioaktivitas sangat penting dalam pengembangan tumbuhan sebagai obat herbal terstandart maupun untuk fitofarmaka. Kajian ini bertujuan untuk menjelaskan pemanfaatan dan bioaktivitas $G$. mangostana sehingga pengembangan maupun pemanfaatannya dapat ditingkatkan

\section{METODE}

Penelitian ini didasarkan pada kajian literatur yang terbit secara online terutama di Google scholar. Beberapa kata kunci yang digunakan adalah Garcinia mangostana, uses of G. mangostana, dan biaoctivities of $G$. mangostana. Literature yang diperoleh diseintesakan sehingga menjelaskan botani, mamfaat dan bioaktivitas $G$. mangostana.

\section{HASIL DAN PEMBAHASAN \\ 1. Botani Garcinia mangostana}

Garcinia mangostana memiliki perawakan G. mangostana berupa pohon, tinggi hingga $30 \mathrm{~m}$. Batang tanpa banir di pangkalnya dan dengan permukaan kulit kayu yang mengelupas, serpihan seperti keripik. Tumbuhan ini mengandung getah warna kuning. Batang saat masih muda berbentuk menyegiempat jika dilihat secara melintang. Daun G. mangostana letaknya berhadapan. Helaian daun jorong atau melebar, bundar telur atau lanset terbalik, panjang $9-25.5 \mathrm{~cm}$ serta lebar 7 $-9 \mathrm{~cm}$. Pangkal daun berbentuk membaji atau tumpul, tepi rata dan ujung runcing atau tumpul. Bunga $G$. mangostana dibedakan menjadi bunga jantan dan bunga betina. Bunga jantan lebih kecil ukurannya. Bunga muncul dari ujung ranting dengan 1 atau jarang $2-3$ bunga betina dan 3 - 5 bunga jantan. Benang sari pada bunga jantan mengelompok menjadi 1 kumpulan dan di bunga jantan juga terdapat putik steril. Bunga betina dengan stigmaa bercuping 4 atau 5. Buah muda $G$. mangostana bewarna kehijauan dan berubah menjadi merah pink atau saat masak penuh ungu gelap, bulat telur, pir, jorong atau membulat. Diameter buah 3 $6 \mathrm{~cm}$. Biji terbungkus oleh salut biji putih, manis (Nazre dkk. 2018; Silalahi dan Mustaqim 2020).

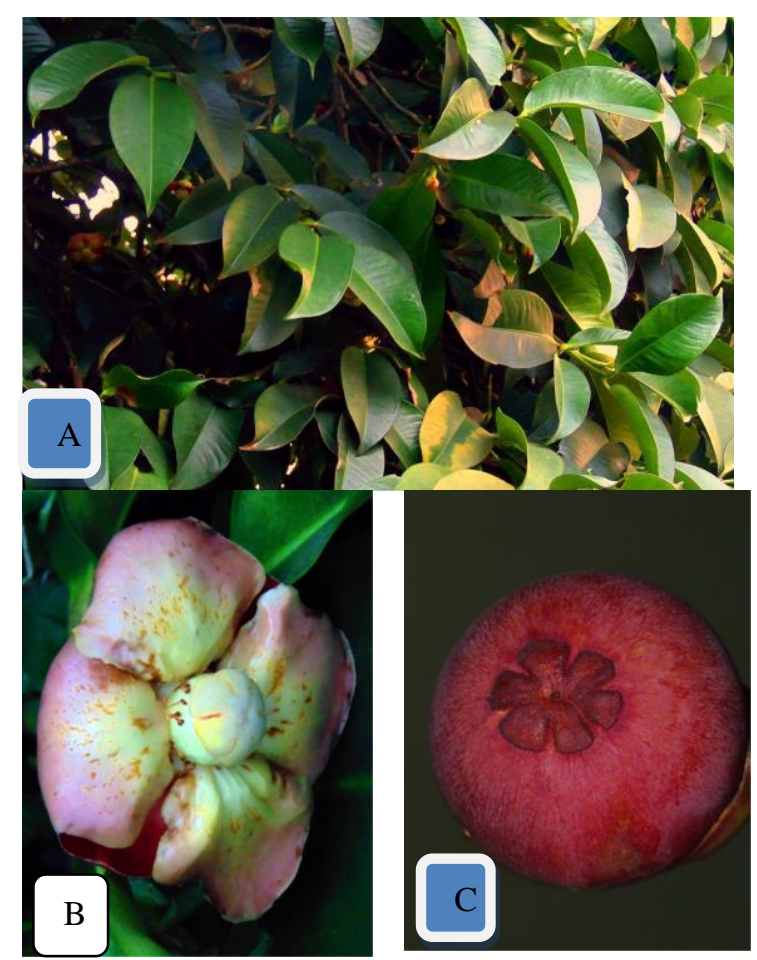

Gambar 1. Manggis atau Garcinia mangostana. A. Ranting dengan daun; B. Bunga; C. Buah 


\section{Manfaat dan Bioaktivitas}

\subsection{Anti Mikroba}

Berbagai mikroba khususnya mikroba patogen mengakibatkan penyakit pada manuasia. Antibiotik merupakan senyawa yang digunakan untuk menghambat pertumbuhan mikroba. Berbagai fakta menunjukkan bahwa terjadi peningkatan resistensi mikroorganisme khususnya bakteri terhadap antibiotik, sehingga pencarian senyawa anti mikroba baru teus dilakukan. Senyawa anti mikroba merupakan senyawa yang menghambat pertumbuhan atau mengakibatkan kematian pada berbagai bakteria atau jamur mikroskopis. Ekstrak etanol pericarp kulit buah $G$. mangostana mengandung dari mangostin yang dapat digunakan sebagai agen antibakteri untuk pengobatan sakit tenggorokan (Jujun dkk. 2008).

$$
\text { Pemanfaatan ekstrak } G \text {. }
$$

mangostana sebagai anti mikroba telah banyak dilaporkan seperti Phuong dkk. (2017), Ragasa dkk. (2010), Suksamrarn dkk. (2003), Seesom dkk. (2013), Radji dkk. (2011). Ekstrak G. mangostana menghambat pertumbuhan Staphylococcus aureus (Phuong dkk. (2017: Radji dkk. 2011; Ragasa dkk. 2010), Escherichia coli, Bacillus subtilis, Pseudomonas aeruginosa (Radji dkk. 2011; Ragasa dkk. 2011), Mycobacterium tuberculosis (Suksamrarn dkk. 2003), Leptospira non-patogen ( $L$. biflexa) dan patogen ( $L$. interrogans, $L$. utumnalis) (Seesom dkk. 2013), Micrococcus luteus (Radji dkk. 2011), Candida albicans, Trichophyton mentagrophytes, dan Aspergillus niger (Ragasa dkk. 2010).

Bioaktivitas G. mangostana sebagai anti mikroba berhubungan dengan kandungan metabolit sekundernya dan jamur endofitnya (Radji dkk. 2011). Phuong dkk. (2017) melaporkan bahwa $\alpha$ mangostin dengan kemurnian 98\% dari perikarp $G$. mangostana menghambat pertumbuhan tiga strain $S$. aureus yaitu $S$. aureus resisten methicillin (MRSA) dan dua strain $S$. aureus sensitif methicilin (MSSA). Konsentrasi hambat minimal (MIC) $\alpha$-mangostin sebesar 4,6 - 9,2 $\mathrm{mmol} / \mathrm{L}$ untuk ketiga jenis $S$. aureus, namun MSSA lebih sensitif terhadap $\alpha-$ mangostin daripada MRSA (Phuong dkk. 2017). Senyawa xanthones terperinilisaasi yang diisolasi dari perikarp dan aril dan biji $G$. mangostana memiliki aktivitas anti tuberkulosis. Senyawa a- dan b-mangostin dan garcinone $B$ menunjukkan penghambatan yang kuat terhadap $\mathrm{M}$. tuberculosis dengan nilai MIC sebesar $6,25 \mathrm{~m} \mathrm{~g} / \mathrm{ml}$ (Suksamrarn dkk. 2003).

Xanthone murni dan ekstrak kasar dari G. mangostana menghambat pertumbuhan Leptospira non-patogen dan pathogen. Ekstrak kasar G. mangostana aktif terhadap semua Leptosipra pathogen dan non patogen dengan MIC mulai dari 200 hingga $\geq 800 \mu \mathrm{g} / \mathrm{ml}$. Garcinone $\mathrm{C}$ merupakan senyawa yang paling aktif melawan patogen $(\mathrm{MIC}=100 \mu \mathrm{g} / \mathrm{ml})$ dan non-patogen Leptospira (MIC $=200$ $\mu \mathrm{g} / \mathrm{ml}$ ) namun konsentrasi ini masih lebih tinggi daripada antibiotik (Seesom dkk. 2013). Radji dkk. (2011) melaporkan sebanyak 10 dari 24 isolat $(41,6 \%)$ jamur endofit yang diisolasi dari daun $G$. mangostana memiliki aktivitas antibakteri terhadap S. aureus, B. subtilis, Escherichia coli, $P$. aeruginosa dan $M$. luteus.

Ekstrak etil asetat dari pericarp beku-kering $G$. mangostana mengandung a-mangostin, gartanin dan dan 3isomangostin (Ragasa dkk. 2010). Pada konsentrasi $\quad 30 \quad \mu \mathrm{g}, \quad \alpha$-mangostin menunjukkan aktivitas antibakteri yang tinggi terhadap $S$. aureus, aktivitas moderat terhadap $C$. albicans, dan aktivitas rendah terhadap $B$. subtilis, $E$. coli, $P$. aeruginosa, T. mentagrophytes, dan A. niger. Senyawa gartanin menunjukkan aktivitas antibakteri yang rendah terhadap E. coli, $P$. aeruginosa, $S$. aureus dan B. subtilis, aktivitas antijamur yang rendah terhadap $C$. albicans dan $T$. mentagrophytes, dan tidak aktif terhadap 
A. niger. Campuran gartanin dan 3isomangostin menunjukkan aktivitas antibakteri yang rendah terhadap $P$. aeruginosa, S. aureus dan B. subtilis, aktivitas antijamur yang rendah terhadap C. albicans dan T. mentagrophytes, dan tidak aktif terhadap E. coli dan A. niger (Ragasa dkk. 2010).

\subsection{Antioksidan}

Senyawa antioksidan merupakan senyawa yang membantu penghambatan radikal bebas yang diduga secara langsung maupun tidak langsung berfungsi mencegah berbagai penyakit yang berhubungan dengan penuaan. Banyak penyakit berkorelasi dengan defisiensi antioksidan (Tjahjania dkk. 2014).

Berbagai senyawa telah diisolasi dari G. mangostana yang diduga berfungsi sebagai antioksidan yaitu asam galat, asam protocatechuic, asam klorogenat, kuersetin, epicatechin, katekin dan sianidin 3-sophoroside (Azima dkk. 2017). Xanthone terprenilasi yang diisolasi dari pericarp G. mangostana memiliki aktivitas antioksidan terdapat pada hampir semua organ $G$. mangostana yaitu pericarp, seluruh buah, empulur, dan daun (PedrazaChaverri dkk. 2008). Ekstrak metanol perikarp G. mangostana mengandung senyawa fenolik dan memiliki kekuatan reduksi serta $\mathrm{Fe}^{2+}$ kegiatan chelating (Kosem dkk. 2007).

Pektin dari perikarp G. mangostana menunjukkan aktivitas antioksidan dengan IC50 sekitar 161,9431,57 ppm (Wathoni dkk. 2019). Ekstrak etil asetat dan aseton pericarp G. mangostana memiliki IC50 untuk menurunkan radikal bebas DPPH (1,1-diphenyl-2-picrylhydrazyl) sebesar $30,01 \mu \mathrm{g} / \mathrm{ml}$ dan 33,32 $\mu \mathrm{g} / \mathrm{ml}$ (Zarena and Sankar 2009). Ekstrak metanol pericarp $G$. mangostana meningkatkan sel bertahan hidup dengan mengurangi kerusakan oksidatif pada sel endotel ECV304 setelah paparan $\mathrm{H}_{2} \mathrm{O}_{2}$, hal ini menunjukkan ekstrak memiliki aktivitas antioksidan dan kemopreventif (Kosem dkk. 2007).

Ekstrat perikarp G. mangostana memiliki aktivitas antioksidan dan neuroprotektif. Berbagai ekstrak buah $G$. mangostana yaitu ekstrak air, 50\% etanol, $95 \%$ etanol dan etil asetat dengan konsentrasi 1, 10, 50 dan100 g/ml memiliki aktivitas antiokasidan yang diuji dengan DPPH. Didasarkan pada aktivitas pembersihan radikal bebas dari ekstrak, dua (air dan etanol 50\%) dipilih untuk aktivitas protektif dalam sel neuroblastoma NG108-15 terhadap stres oksidatif yang diinduksi $\mathrm{H}_{2} \mathrm{O}_{2}$ dan untuk viabilitas sel menggunakan 3- (4,5-dimethylthiazol-2yl) -2,5-diphenyltetrazolium bromide assay. Semua ekstrak menunjukkan aktivitas antioksidan namun ekstrak air dan ekstrak etanol 50\% menunjukkan pembersihan radikal bebas yang tinggi dengan nilai IC 50 sebesar 34,98 $\pm 2,24$ dan $30,76 \pm 1,66 \mathrm{~g} / \mathrm{ml}$ secara berurutan. Ekstrak air dan etanol 50\% menunjukkan aktivitas neuroprotektif pada sel NG10815. Aktivitas tertinggi diamati pada konsentrasi $50 \mathrm{~g} / \mathrm{ml}$ untuk air dan $50 \%$ etanol. Untuk uji sitotoksisitas, tidak ada ekstrak toksik pada sel kecuali pada konsentrasi tinggi100 g/ml (Weecharangsan dkk. 2006).

$$
\text { Bioaktivitas ekstrak } G \text {. }
$$

mangostana sebagai antioksidan berhubungan dengan kandungan metabolit sekundernya. Ekstrak air, metanol, dan heksana pericarp G. mangostana mengandung fenolik seperti $\alpha$-mangostin, epicatechin, dan tannin (Ngawhirunpat dkk. 2010). Aktivitas pemulungan radikal bebas 1,1-difenil-2-pikrillhidrazil (DPPH, ekstrak air menunjukkan lebih tinggi aktivitas dari ekstrak metanol dan ekstrak heksana. Senyawa $\alpha$-Mangostin, epicatechin, dan tannin memiliki antioksidan dan pemulung radikal bebas (Ngawhirunpat dkk. 2010). 


\subsection{Anti Kanker}

Kanker merupakan salah satu penyebab kematian pada manusia yang disebakan oleh pertumbuhan sel yang tidak terkendali seperti kanker payudara dan kanker prostat. Senyawa yang digunakan sebagai anti kanker merupakan senyawa yang mampu menghambat pertumbuhan sel atau mengakibatkan apostosis (Doi dkk. 2009; Aisha dkk. 2012). Tiga langkah kunci dalam metastasis tumor adalah penghambatan migrasi sel, selinvasi dan clonogenicity. Ekstrak dan $\alpha$-mangostin mengatur MAPK / ERK, c-Myc /Max, dan jalur pensinyalan sel p53. Ekstrak xanthones, ketika diberikan ke tikus, menyebabkan pertumbuhan yang signifikan penghambatan tumor subkutan HCT 116 sel karsinoma kolorektal (Aisha dkk. 2012). Senyawa $\alpha$-mangostin menginduksi apoptosis, peningkatan aktivitas caspases dan penurunan potensi membran mitokondria, penahanan siklus sel pada fase G1 dan penurunan populasi sel dalam fase Sdan G2/M (Doi dkk. 2009).

Senyawa mangostenones $\mathrm{C}$ yang diisolasi dari buah $G$. mangostana menunjukkan sifat sitotoksik terhadap tiga line sel kanker manusia, epidermoid carcinoma mulut (KB), kanker payudara (BC-1), dan kanker paru-paru sel kecil (NCI-H187), dengan nilai IC50 2,8, 3,53, dan $3,72 \mathrm{~m} \mathrm{~g} / \mathrm{ml}$, secara berurutan (Suksamrarn dkk. 2006). Senyawa amangostin merupakan senyawa utama yang menunjukkan yang paling kuat efek terhadap sel BC-1 dengan nilai IC50 0,92 $\mathrm{mg} / \mathrm{ml}$, aktivitas yang lebih besar dari standar obat ellipticine (IC50 1,46m g/ml). Senyawa a-mangostin juga menunjukkan aktivitas tertinggi melawan sel $\mathrm{KB}$, sedangkan gartanin menampilkan aktivitas terkuat melawan sel NCI-H187 dengan nilai IC50 masing-masing sebesar 2,08 $\mathrm{mg} / \mathrm{ml}$ dan 1,08 mg/ ml (Suksamrarn dkk. 2006).
Panaxanthone (sekitar $80 \% \quad \alpha$ mangostin dan $20 \% \gamma$-mangostin) memiliki aktivitas sebagai anti kanker payudara. Dalam percobaan laboratorium tumor mammae pada tikus, diinduksi melalui inokulasi $\mathrm{BALB} / \mathrm{c}$ syngeneic dengan sel BJMC3879, kemudian diobati dengan panaxanthone pada $0,2.500$, atau 5.000 ppm dalam makanannya. Secara in vivo volume tumor secara signifikan ditekan pada tikus dengan panaxanthone 2.500 dan 5.000 ppm yang diberi pada makanannya. Banyaknya metastasis paru secara signifikan lebih rendah dikelompok 5.000 ppm. Metastasis kelenjar getah bening juga cenderung menurun pada kelompok 5.000 ppm tetapi tidak signifikan. Efek antitumor panaxanthone dikaitkan dengan peningkatan kematian sel apoptosis, anti proliferasi dan antiangiogenesis (Doi dkk. 2009). Ekstrak metanol dan ekstrak heksana $G$. mangostana menunjukkan sitotoksisitas sedang, sedangkan $\alpha$ mangostin menunjukkan sitotoksisitas yang kuat (Ngawhirunpat dkk. 2010).

Ekstrak etanol perikarp $G$. mangostana memiliki aktivitas anti kanker kulit pada karsinoma sel skuamosa manusia A-431 dan melanoma SK-MEL28. Ekstrak etanol perikarp G. mangostana $10 \mu \mathrm{g} / \mathrm{ml}$ menginduksi peningkatan $18 \%$ pada apoptosis dini dibandingkan sel yang tidak diobati (2\%). Apoptosis meningkat secara signifikan setelah pengobatan MPEE dari sel-sel SK-MEL-28. Ekstrak etanol perikarp G. mangostana menunjukkan efek anti kanker kulit yang kuat pada dua jalur sel kanker kulit dengan potensi sebagai agen kanker anti-kulit (Wang dkk. 2020).

Perikarp buah $G$. mangostana merupakan sumber yang kaya akan xanthones merupakan kelompok senyawa polyphenolic dengan senyawa aromatic trisiklik yang berbeda dan memiliki aktivitas sebagai anti kanker (Li dkk. 2013). A-mangosten merupakan senyawa poliphenolik G. mangostana yang mampu 
melawan sel kanker payudara dan kanker prostat. Ekstrak xanthones menginduksi apaostosis sel dan menghambat poliferasi sel kanker secara in vitro dan in vivo (Li dkk. 2013). Hal tersebut membuktikan bahwa target polyphenol terlibat dalam memodulasi siklus sel dan apostosis sehingga sangat potensial dgunakan untuk kemopreventif untuk kanker payudara dan prostat (Li dkk. 2013)

\subsection{Antiinflamasi}

Dua senyawa xanthones yaitu a dan c-mangostin yang diisolasi dari pericarp $G$. mangostana secara signifikan menghambat produksi nitric oxide (NO) dan PGE2 dari sel RAW 264,7 yang distimulasi lipopolysaccharide (LPS). Nilai IC50 untuk penghambatan produksi $\mathrm{NO}$ oleh a dan c-mangostin sebesar 12,4 dan 10,1 $\mu \mathrm{M}$ secara berurutan. Setelah aktivitas enzim iNOS distimulasi oleh LPS selama 12 jam, pengobatan dengan a- atau c-mangostin pada $5 \mu \mathrm{g} / \mathrm{ml}(12,2$ dan $12,6 \mu \mathrm{M}$ secara berurutan). Data menunjukkan bahwa aktivitas penghambatan a- dan cmangostin bukan karena penghambatan langsung aktivitas enzim iNOS. Di sisi lain, ekspresi iNOS dihambat oleh a- dan c-mangostin dalam sel RAW 264,7 yang distimulasi LPS, tetapi tidak oleh COX-2 (Chen dkk. 2007)

\subsection{Antidiabetes Mellitus}

Diabetes mellitus merupakan salah satu gangguan metabolisme pada manusia yang menyebabkan kadar gula dalam dalam plasma darah di atas normal, oleh karena itu senyawa yang digunakan sebagai anti diabetes mellitus merupakan senyawa yang menghambat pemecahan karbohidrat (Munin dan Hanani 2011), atau enzim yang terlibat dalam pemecahan karbohidrat. Diabetes mellitus secara langsung maupun tidak langsung berdampak pada fungsi ginjal.

Ekstrak perikarp G. mangostana memiliki efek reno protektif (melindungi ginjal) pada kreatinin plasma dan tubulus proksimal ginjal tikus diabetes yang diinduksi streptozotocin (Ansori dkk. 2019). Metformin merupakan salah satu obat komersial yang digunakan untuk mengatasi penyakit diabetes mellitus. Pada percobaan di laboratorium, diabetes diinduksi dengan injeksi Streptozotocin (STZ) yang diberi secara intraperitoneal. Tikus yang diberi STZ dengan dosis rendah $30 \mathrm{mg} / \mathrm{kg}$ berat badan setiap hari untuk lima hari berturut-turut kemudian diberi ekatrak G. MANGOSTANA akan mengurangi kadar kreatinin plasma dan memperbaiki tubulus proksimal ginjal (Ansori dkk. 2019).

\subsection{Hepatoprotektif}

Senyawa
merupakan senyawa yang dapat
memperbaiki fungsi hati maupun
memperbaiki fungsi hati. Fraksi $\mathrm{CHCl}_{3}$
mengandung senyawa turunan xanthone
yaitu $\alpha$-mangostin, $\gamma$-mangostin, gartanin,
deoxygartanin, 1-isomangstanin dan
garcinone E memiliki aktivitas hepatoprotektif. Semua senyawa turunan xanthon menghambat secara signifikan viabilitas HSC-T6 sel stellate hati sebagai sistem uji in vitro. Diantaranya, senyawa $\alpha$-mangostin dan $\gamma$-mangostin menghambat viabilitas HSC-T6 dalam dosis dan perilaku yang tergantung waktu. Senyawa $\alpha$-mangostin dan $\gamma$-mangostin secara signifikan mengurangi kandungan kolagen, suatu karakteristik patologis dari fibrosis hati. G. mangostana dan konstituennya mungkin bermanfaat untuk pengobatan fibrosis hati (Chin dkk. 2011).

\section{KESIMPULAN}

1. Masyarakat lokal di Asia Tenggara telah menggunakan G. mangostana sebagai obat tradisional untuk pengobatan sakit perut, diare, disentri, luka terinfeksi, nanah, dan ulkus kronis. 
2. Garcinia mangostana mangostana memiliki bioaktivitas sebagai anti mikroba, antioksidan, anti kanker, antiinflamasi dan anti diabetes mellitus

\section{DAFTAR RUJUKAN}

Asai, F., Tosa, H., Tanaka, T. and Iinuma, M. 1995. A xanthone from pericarps of Garcinia Mangostana. Phytochemistry 39(4): 943-944.

Aisha, A.F.A., Abu-Salah, K.M., Ismail, Z. and Majid, A.M.S.A. 2012. In vitro and in vivo anti-colon cancer effects of Garcinia mangostana xanthones extract. BMC Complementary and Alternative Medicine 12(104): 1-10.

Ansori, A.N.M., Susilo, R.J.K., Hayaza, S., Winarni, D. and Husen, S.A. 2019. Renoprotection by Garcinia mangostana L. pericarp extract in streptozotocin-induced diabetic mice. Iraqi Journal of Veterinary Sciences 33(1): 13-19.

Azima, A.M.S., Noriham, A. and Manshoor, N. 2017. Phenolics, antioxidants and color properties of aqueous piG. mangostanaented plant extracts: Ardisia colorata var. elliptica, Clitoria ternatea, Garcinia mangostana and Syzygium cumini. Journal of Functional Foods 38: 232-241.

Chen, L.G., Yang, L.L. and Wang, C.C. 2007. Anti-inflammatory activity of mangostins from Garcinia mangostana. Food. Chem. Toxicol. doi:10.1016/j.fct.2007.09.096

Chin, Y.W., Shin, E., Hwang, B.Y. and Lee, M.K. 2011. Antifibrotic constituents from Garcinia mangostana. Natural Product Communications 6(9): 1267-1268.

Doi, H., Shibata, M.A, Shibata, E., Morimoto, J., Akao, Y., Iinuma, M., Tanigawa, N., and Otsuki, Y. 2009. Panaxanthone isolated from pericarp of Garcinia mangostana L. supresses tumor growth and metastasis of a mouse model of mammary cancer. Anticancer Research 29: 2485-2496.

Jujun, P., Pootakham, K., Pongpaibul, Y., Duangrat, C. and Tharavichitkul, P. 2008. Acute and repeated dose 28day oral toxicity study of Garcinia mangostana Linn. rind extract. CMU. J. Nat. Sci. (2): 199-208.

Kosem, N., Han, Y.H, and Moongkarndi, P. 2007. Antioxidant and cytoprotective activities of methanolic extract from Garcinia mangostana hulls. Science Asia 33: 283-292.

Li, G., Thomas, S. and Johnson, J.J. 2013. Polyphenol from the mangosteen (Garcinia mangostana) fruit for breast and prostate cancer. Frontier in Pharmacology 4(80): 1-4.

Munin, H, dan Hanani, E. 2011. Fitoterapi Dasar. Dian Rakyat. Depok. Jawa Barat.

Nazre, M., Newman, M.F., Pennington, R.T. and Middleton, D.J. 2018. Taxonomic revision of Garcinia section Garcinia (Clusiaceae). Phytotaxa 373(1): 1-52.

Ngawhirunpat, T., Opanasopi, P., Sukma, M., Sittisombut, C., Kat, A. and Adachi, I. 2010. Antioxidant, free radical-scavenging activity and cytotoxicity of different solvent extracts and their phenolic constituents from the fruit hull of mangosteen (Garcinia mangostana), Pharmaceutical Biology 48(1): 5562.

Pedraza-Chaverri, J., Cárdenas-Rodríguez, N., Orozco-Ibarra, M. and PérezRojas, J.M. 2008. Medicinal properties of mangosteen (Garcinia mangostana). Food and Chemical Toxicology 46: 3227-3239.

Phuong, N.T.M., Quang, N.V., Mai, T.T., Anh, N.V., Kuhakarn, C., Reutrakul, V. and Bolhuis, A. 2017. 
Antibiofilm activity of a-mangostin extracted from Garcinia mangostana L. against Staphylococcus aureus. Asian Pacific Journal of Tropical Medicine 10(12): 1154-1160.

Ragasa, C.Y., Crisostomo, C.J.J., Garcia, K.D.C. and Shen, C.C. 2010. Antimicrobial xanthones from Garcinia mangostana L. Philipp. Scient 47: 63-75.

Radji, M., Sumiati, A., Rachmayani, R. and Elya, B. 2011. Isolation of fungal endophytes from Garcinia mangostana and their antibacterial activity. African Journal of Biotechnology 10(1): 103-107.

Seesom, W., Jaratrungtawee, A., Suksamrarn, S., Mekseepralard, C., Ratananukul, P. and Sukhumsirichart, W. 2013. Antileptospiral activity of xanthones from Garcinia mangostana and synergy of gamma-mangostin with penicillin G. BMC Complementary and Alternative Medicine 13(182): 16.

Silalahi, M. dan Mustaqim, W.A. 2020. Tumbuhan Berbiji Di Jakarta Jilid 1: 100 Jenis-Jenis Pohon Terpilih. UKI Press, Jakarta. P: 47-48

Suksamrarn, S., Suwannapoch, A.N., Phakhodee, A.W., Thanuhiranlert, A.J., Ratananukul, A.P., Chimnoi, A.N. and Suksamrarn, A. 2003. Antimycobacterial activity of prenylated xanthones from the fruits of Garcinia mangostana. Chem. Pharm. Bull. 51(7): 857-859.

Suksamrarn, S., Komutiban, A.O., Ratananukul, A.P., Chimnoi, A.N., Lartpornmatulee, B.N. and Suksamrarn, A. 2006. Cytotoxic prenylated xanthones from the young fruit of Garcinia mangostana. Chem. Pharm. Bull. 54(3) 301-305.

Tjahjani, S., Widowati, W., Khiong, K., Suhendra, A. and Tjokropranoto, R. 2014. Antioxidant properties of Garcinia mangostana L (Mangosteen) Rind. Procedia Chemistry 13: 198-203.

Wathoni, N., Shan, C.Y., Shan, W.Y., Rostinawati, T., Indradi, R.B., Pratiwi, R. and Muchtaridi, M. 2019. Characterization and antioxidant activity of pectin from Indonesian mangosteen (Garcinia mangostana L.) Rind. Heliyon 5: 02299.

Weecharangsan, W., Opanasopit, P., Sukma, M., Ngawhirunpat, T., Sotanaphun, U. and Siripong, P. 2006. Antioxidative and neuroprotective activities of extracts from the fruit hull of mangosteen (Garcinia mangostana Linn.). Med Princ Pract 15: 281-287.

Wang, J.J., Shi, Q.H., Zhang, W. and Sanderson, B.J.S. 2020. Anti-skin cancer properties of phenolic-rich extract from the pericarp of mangosteen (Garcinia mangostana Linn.). Food and Chemical Toxicology 50: 3004-3013.

Yodhnu, S., Sirikatitham, A. and Wattanapiromsaku, C. 2009. Validation of LC for the Determination of $\alpha$-Mangostin in mangosteen peel extract: a tool for quality assessment of Garcinia mangostana L. Journal of Chromatographic Science 47. 